\title{
Color parameters applied to pedotransfer functions in the estimation of soil attributes ${ }^{1}$
}

\section{Parâmetros da cor aplicados a funções de pedotransferência na estimativa de atributos do solo}

\author{
Nara Núbia de Lima Cruz²; Ronny Sobreira Barbosa ${ }^{3}$; \\ Marcio Cleto Soares de Moura'; Daniel De Bortoli Teixeira ${ }^{5}$; \\ José Marques Júnior ${ }^{6}$; João de Deus Ferreira e Silva ${ }^{7 *}$
}

\begin{abstract}
Global demands for an increased food production have prompted scientists to create technological innovations in various segments of the agricultural and environmental sectors. The use of diffuse reflectance spectroscopy in soil color determination to estimate its attributes is an example of these advances. Thus, the aim of this research was to identify the potential of the three parameters of the Munsell color system (Hue, Value, and Chroma) in estimating different chemical and particle size attributes by pedotransfer functions in a Typic Hapludox in the Cerrado of Piauí State, Brazil. This soil showed a yellowish color due to the goethite and low contents of bases and organic carbon. Among the calibrated pedotransfer functions, we observed that phosphorus, aluminum, hydrogen, potential acidity, potential cation exchange capacity, and base saturation could be estimated by Hue, while clay content by Value, and Chroma used to estimate hydrogen, potential acidity, and cation exchange capacity. We conclude that the parameter color could be used to estimate soil attributes.
\end{abstract}

Key words: Cerrado of Piauí State. Diffuse reflectance spectroscopy. Linear regression. Munsell color system. Sandy-loam soil. Typic Hapludox.

\section{Resumo}

As demandas mundiais por aumento na produção de alimentos vêm instigando os cientistas a criarem inovações tecnológicas em vários segmentos dos setores agrícolas e ambientais. $\mathrm{O}$ uso da espectroscopia de reflectância difusa na determinação da cor do solo para a estimativa de seus atributos é um exemplo destes avanços. Assim, objetivou-se com esta pesquisa identificar o potencial dos três parâmetros do sistema Munsell de cores (Matiz, Valor e Croma) em estimar diferentes atributos químicos e granulométricos por funções de pedotransferência, em LATOSSOLO AMARELO Distrófico típico no Cerrado do Estado do Piauí, Brasil. O solo apresentou coloração amarelada, como reflexo da goethita e também baixos teores de bases e carbono orgânico. Dentre as funções de pedotransferência calibradas,

1 Parte do Trabalho de Mestrado da primeira autora, apresentado à Universidade Federal do Piauí, UFPI.

2 Discente de Doutorado em Ciência do Solo, Universidade Federal Rural do Pernanbuco, UFRPE, Recife, PE, Brasil. E-mail: nnlc.16@hotmail.com

3 Prof., UFPI, Campus Professora Cinobelina Elvas, Bom Jesus, PI, Brasil. E-mail: ronny.barbosa@ufpi.edu.br

4 Prof., UFPI, Campus Ministro Petrônio Portela, Teresina, PI, Brasil. E-mail: marcio@ufpi.edu.br

5 Prof., Universidade Marília, UNIMAR, Marília, SP, Brasil. E-mail: daniel.dbt@hotmail.com

6 Prof., Universidade Estadual Paulista, UNESP, Campus Jaboticabal, Jaboticabal, SP, Brasil. E-mail: marques@fcav.unesp.br

7 Discente de Graduação em Engenharia Agronômica, UFPI, Campus Professora Cinobelina Elvas, Bom Jesus, PI, Brasil. E-mail: joaodeus.caf@gmail.com

* Author for correspondence 
observamos que fósforo, alumínio, hidrogênio, acidez potencial, capacidade de troca catiônica potencial e saturação por bases podem ser estimada pela matiz, enquanto o teor de argila pode ser estimada pelo valor e o croma pode ser usado para estimar também hidrogênio, acidez potencial e capacidade de troca catiônica. Concluímos que é possível usar a cor para estimar atributos do solo.

Palavras-chave: Cerrado piauiense. Espectroscopia de reflectância difusa. Latossolo amarelo distrófico típico. Regressão linear. Sistema munsell de cores. Solo franco-arenoso.

\section{Introduction}

The constant demands for an increasing world food production have been pushing scientists to create technological innovations in various segments of the agricultural and environmental sectors. Some of these advances are related to the use of spectra in different wavelength ranges for characterizing and monitoring components related to agriculture. For instance, Ascheri et al. (2014) used spectra in the 2500 to $25000 \mathrm{~nm}$ range, which corresponds to the Mid-infrared (MIR), to characterize the starch extracted from Cissus simsiana roots Roem. \& Schult. Dranski et al. (2016) used spectra at $550 \mathrm{~nm}$, which is within the range of the visible (VIS) spectrum that covers the range between approximately 300 and $800 \mathrm{~nm}$, to estimate the concentration of chlorophyll pigments in leaves of Eucalyptus dunnii. Studies such as these are directed to the creation and/or improvement of techniques that enable the greater detailing of information about the resources used in agriculture, including soil attributes (STIGLITZ et al., 2017).

One of the ways of acquiring these spectra is by diffuse reflectance spectroscopy (DRS) (DEMATTÊ; TERRA, 2014). This technique allows studying the behavior of soil components at different wavelengths $(\lambda)$ (NONAKA et al., 2016). During DRS reading, the light incident on a sample is reflected diffusely and can be converted into the tristimulus parameters $\mathrm{X}, \mathrm{Y}$, and $\mathrm{Z}$ (imaginary axes) proposed by the Commission Internationale de l'Eclairage (CIE) in 1976. These parameters are related to the way in which the human body recognizes the primary colors of the electromagnetic spectrum, represented by Red, Green, and Blue (RGB). Afterwards, they are used to determine the parameters Hue (wavelength of light), Value (brightness or tone), and Chroma (purity or intensity of color in relation to gray) belonging to the Munsell color system, which is usually used for various purposes in agriculture such as monitoring the quality of agricultural products (RUBIO et al., 2013) and determining soil color to a field level (KIRILLOVA et al., 2015).

Color found analytically and perceptible to the human eyes portrays the response of the configuration and influence of several soil attributes related to its expression, both by the combined response of physical and chemical attributes and by the more intense expression of a single attribute separately (SORIANO-DISLA et al., 2014). The main components that promote changes in soil spectral behavior are organic matter (OM) and iron oxides (BAUMANN et al., 2016; VODYANITSKII; KIRILLOVA, 2016). However, due to the great variation among soils, a relational pattern between color and specific attributes could not be built without studying each environment individually. Gómez et al. (2013) used DRS to estimate the stability of aggregates in Mediterranean soils. Dantas et al. (2014), in turn, used color to estimate erodibility in cohesive soils in the eastern Maranhão State, Brazil. Peluco et al. (2015) used the color of soil to map the adsorbed phosphorus in soils originating from basalt in São Paulo State, Brazil. In this same Brazilian state, Carmo et al. (2016) correlated color expression with soil attributes and used it to separate agricultural areas regarding their productive potential for coffee.

The Cerrado of Piauí, which has remarkable relevance due to its characteristics of climate, relief, and soil favorable for agricultural production (SILVA et al., 2017), cannot be exempted from these studies. The absence of information on the 
soils of this territory compromises the feasibility of mapping soil attributes in large areas, which would facilitate the decision making related to a better crop management, promoting the reduction of environmental impacts resulting from the agriculture in these places. According to Fernandes et al. (2016), among others, the study of soil characteristics in the Cerrado region allows creating information that supports the use of sustainable techniques of land use and soil management.

Due to a lack of information for the decision making related to the chemical and physical management of these areas, farmers use traditional methodologies that promote a large waste production, are destructive, and have a high cost. Therefore, these observations are often made in a few composite samples and their results are extrapolated to large areas, increasing the probability of underestimating or overestimating management measures (liming, fertilization, scarification, etc.).

Thus, this research aimed to identify the potential of the three parameters of the Munsell color system (Hue, Value, and Chroma) in estimating different chemical and particle size attributes by pedotransfer functions in a Typic Hapludox in the Cerrado of Piauí State, Brazil.

\section{Materials and Methods}

\section{Location and sampling}

The experiment was carried out in the Cerrado area of Bom Jesus, Piauí State (Northeast of Brazil) (Figure 1). The soil of the study area is classified as a sandy-loam textured Typic Hapludox (SANTOS et al., 2013). This soil originates from sedimentary clusters composed, mainly, by sandstones of the Balsas Group, Piauí Formation. The end of sedimentation that originated the soil of this region is attributed to a generalized uplift resulting from the Gondwanide Orogeny corresponding to the Paleozoic era. According to Köppen, regional climatic classification is Aw, defined as a humid tropical climate with a rainy season in the summer and a dry season in the winter, average annual precipitation between 900 and $1200 \mathrm{~mm}$ (concentrated from December to March), and temperatures ranging from 18 to $36^{\circ} \mathrm{C}$.

Figure 1. Location of the experimental area in the Cerrado of Piauí State, Brazil.

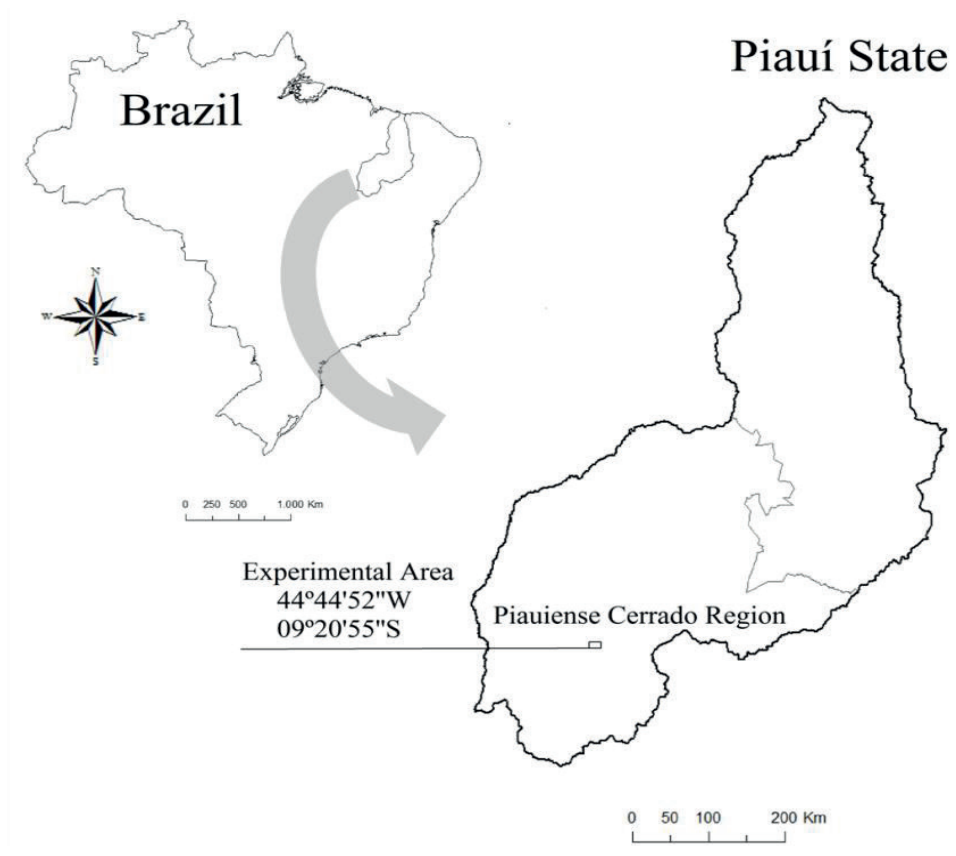


The experimental area has a three-year history of soybean (Glycine max) production intercropped with millet (Pennisetum glaucum) under no-tillage system. In 2013, in order to obtain a $50 \%$ base saturation, the soil of the area was corrected with limestone in surface and fertilized with $500 \mathrm{~kg} \mathrm{ha}^{-1}$ of 2-20-10 $\left(\mathrm{N}^{-} \mathrm{P}_{2} \mathrm{O}_{5}-\mathrm{K}_{2} \mathrm{O}\right)$ and $120 \mathrm{~kg} \mathrm{ha}{ }^{-1}$ of $\mathrm{KCl}$ in a single application.

For this study, we used two soybean production areas in the same region (areas A and B). In both areas, 10 disturbed soil samples $(500 \mathrm{~g})$ were collected in the soil surface horizon $(0-0.25 \mathrm{~m})$. The 10 samples from area A were used for calibrating the pedotransfer functions, while the other 10 samples from area B were used for validating these functions. We opted for a small number of samples as long as soil attributes can be estimated by color with a small number of samples (PELUCO et al., 2015).

\section{Spectral analyses}

Diffuse reflectance spectroscopy values were determined by using a Lambda 950 laboratory sensor equipped with an integrating sphere $(0.16$ $\mathrm{m})$ at intervals of $1 \mathrm{~nm}$ with an integration time of 0.2 seconds, with scanning in the range of 380 to $780 \mathrm{~nm}$ (visible range) (Figure 2). To avoid shading by micro-reliefs, samples were previously milled in an agate mortar until a constant color. Spectral values were converted into tristimulus $\mathrm{X}, \mathrm{Y}$, and $\mathrm{Z}$ and these imaginary coordinates were deduced for parameters of the Munsell color system (Hue, Value, and Chroma). For this, the software Munsell Conversion version 6.4 was used.

Figure 2. Diffuse reflectance spectra of samples in the visible range.

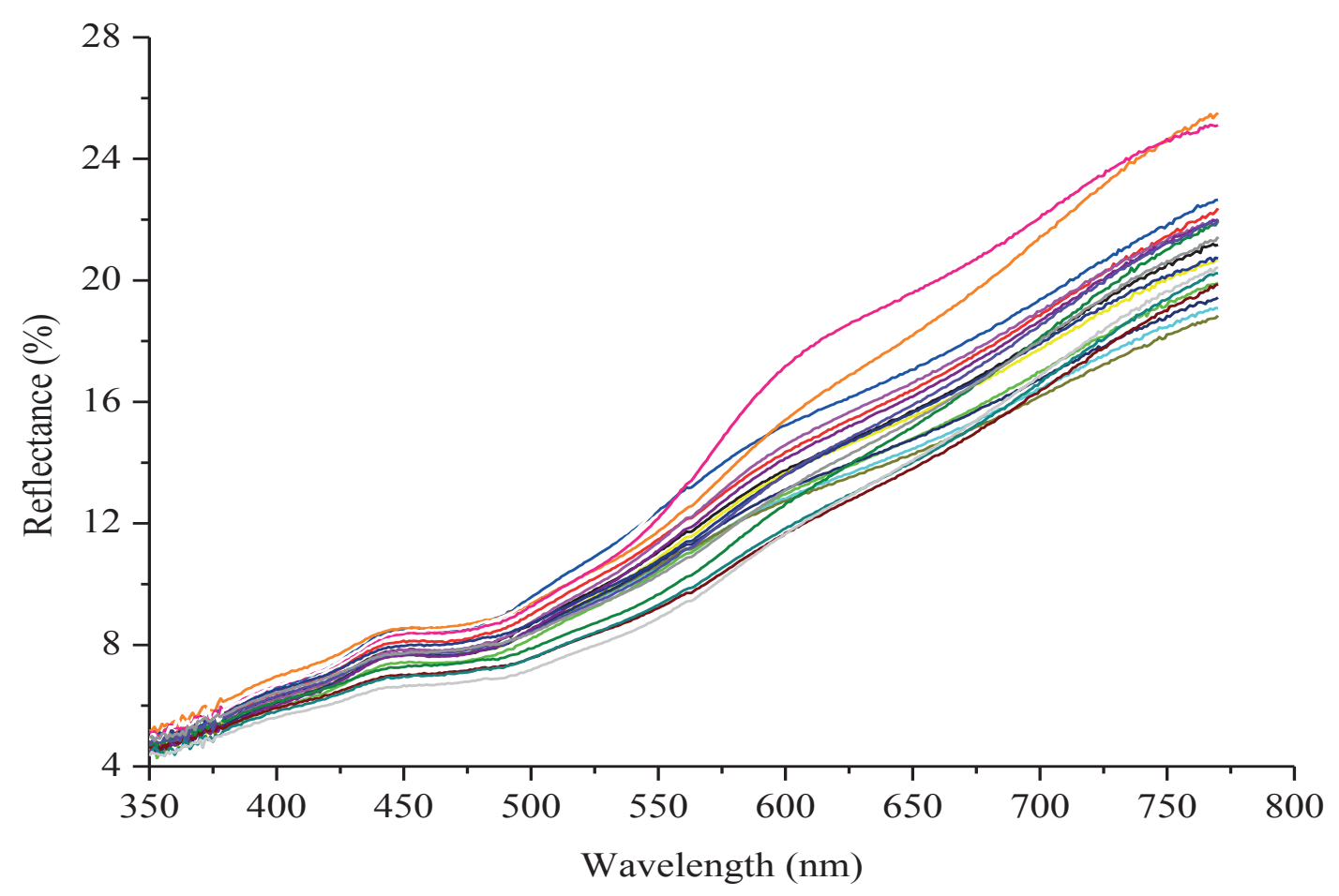


Laboratory methods

The analyses of calcium + magnesium $(\mathrm{Ca}+\mathrm{Mg})$, potassium $\left(\mathrm{K}^{+}\right)$, phosphorus $(\mathrm{P})$, total organic carbon (TOC), aluminum $\left(\mathrm{Al}^{3+}\right)$, hydrogen $\left(\mathrm{H}^{+}\right)$, potential acidity $(\mathrm{H}+\mathrm{Al})$, effective cation exchange capacity $\left(\mathrm{CEC}_{4.0}\right)$, potential cation exchange capacity $\left(\mathrm{CEC}_{7.0}\right)$, base saturation $(\mathrm{V})$, sum of bases (SB), and quantification of sand, silt, and clay were carried out by using the methods proposed by Donagema et al. (2011).

\section{Data analysis}

In order to observe data behavior, descriptive analyses were carried out with the values of mean, median, minimum, maximum, standard deviation, coefficient of variation, asymmetry, and kurtosis of all attributes. Calculations of empirical distributions, descriptive statistics, and Tukey's test for comparison of the attribute means between areas were performed using the software Minitab 14.1.

Pedotransfer functions were deduced by simple regression between attribute values and their corresponding Hue, Value, and Chroma. The functions that presented significance were also validated by simple regression by comparing the real value with the value estimated by pedotransfer functions. In order to observe the precision and accuracy of models, values of coefficient of determination $\left(\mathrm{R}^{2}\right)$ and root mean square error (RMSE) were used. According to Holmes et al. (2000), RMSE is obtained by means of discrete sample points, being common its use in estimating the error or uncertainty in the sites. RMSE was calculated according to Equation (1):

$$
\mathrm{RMSE}=\sqrt{\frac{1}{\mathrm{n}}} \sum_{\mathrm{i}=1}^{\mathrm{n}}(\mathrm{ei}-\mathrm{mi})^{2}
$$

Wherein: $\mathrm{n}$ is the number of observations, ei is the value estimated by the pedotransfer function of the variable of interest, and mi is the measured value of the variable of interest.

\section{Results and Discussion}

\section{Soil color}

Most of the samples presented a Hue between 2.5YR and 7.5YR (Figure 3), which is a reflection of the goethite presence (NONAKA et al., 2016). However, we cannot exclude the possibility of a low occurrence of hematite and/or maghemite since some samples presented a Hue close to 5 YR (Figure 3). Goethite formation needs an oxidic environment with a slightly high moisture regime $(\alpha-\mathrm{FeOOH})$ (VODYANITSKII; KIRILLOVA, 2016). The climate characteristic of the Cerrado of Piauí State (abundant/concentrated rains and high temperatures) provides perfect conditions for goethite formation. On the slope, a reddish color can be observed in the local parent material due to iron oxidation in the Sandstone; however, a greater expression of the yellow color can be observed in the subsurface horizons on this material. This information strengthens the thesis that the soil of the Cerrado of Piauí State had a higher moisture regime during its formation. In addition, we can verify other morphological characteristics that indicate the role of water in this soil formation such as occurrences of nodules and concretions of different sizes at the top of the landscape (watershed).

Chroma varies from 0 (neutral gray) to 20 (maximum chroma), but in soils, it varies from 1 to 8 (RABENHORST et al., 2014). In the studied soil, most of the samples presented a Chroma between 4 and 6 (Figure 3). The higher the value of this parameter is, the greater the color expression (RABENHORST et al., 2014). Thus, the soil of this study presents little interference of components that decrease Chroma expression such as high levels of organic carbon that tend to increase soil darkening (DEMATTÊ et al., 2011; BAUMANN et al., 2016). The Value used for the chromatic diagramming of samples was 4 (average value of all samples) (Figure 3). Considering that Value varies from 0 (pure black) to 10 (pure white), the soil of the studied region has intermediate levels of brightness, 
with tonality close to gray (Value $=5$ ). Many are the factors responsible for these characteristics, however, the organic matter contents stand out as the main responsible for masking the action of all other agents since it acts in soil darkening (BAUMANN et al., 2016). A color close to gray is an indicator of the possible stationary presence of water during this soil formation (RABENHORST et al., 2014), thus configuring a reducing environment, even with this soil currently at the top of the landscape.

Figure 3. Distribution of soil color used in the study in part of the CIE chromaticity diagram with the determination of the Munsell system parameters.

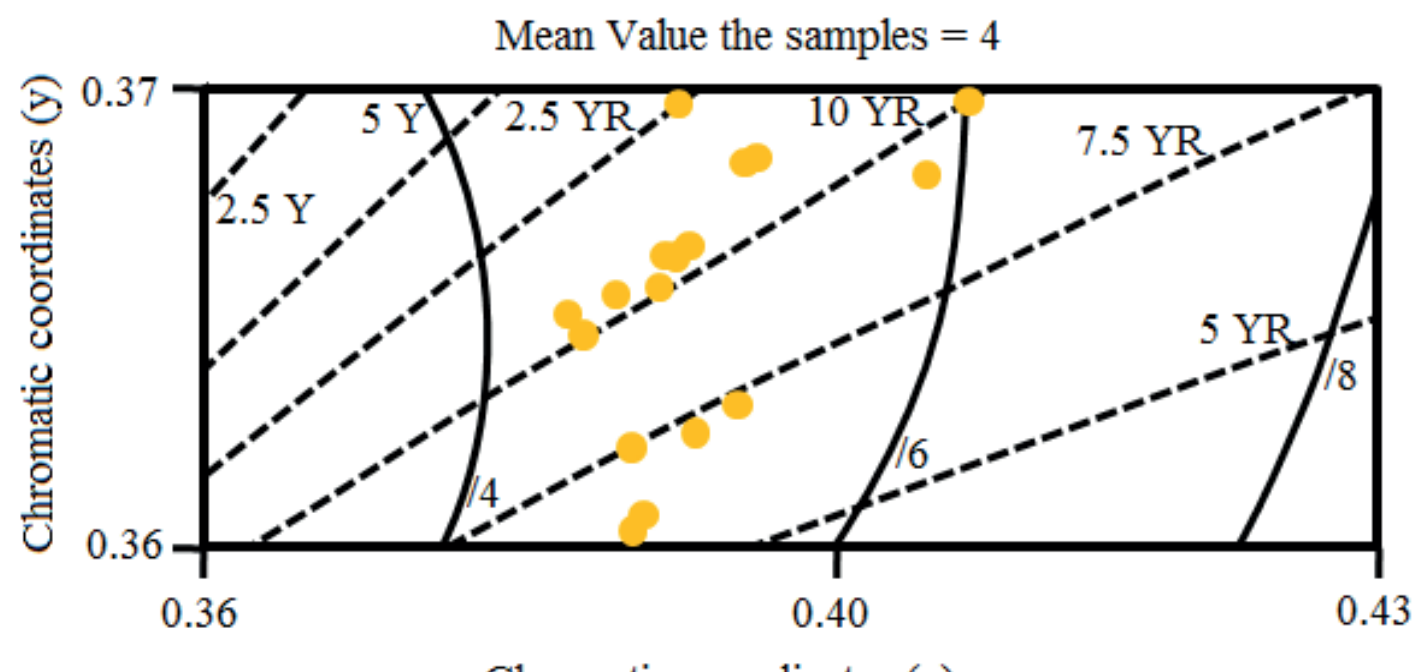

Chromatic coordinates $(\mathrm{x})$

\section{Soil attributes}

The attributes $\mathrm{CEC}_{7.0}$ and sand presented a low variation $(\mathrm{CV}<10 \%)$, while $\mathrm{Ca}+\mathrm{Mg}, \mathrm{H}^{+}, \mathrm{H}+\mathrm{Al}$, $\mathrm{CEC}_{4.0}, \mathrm{~V}, \mathrm{SB}$, and clay presented a medium variation $(10<\mathrm{CV}<20 \%)$ (Table 1$)$. The attribute TOC presented a high variation $(20<\mathrm{CV}<30 \%)$ and the attributes $\mathrm{Al}^{3+}, \mathrm{P}, \mathrm{K}^{+}$, and silt presented a very high variation $(\mathrm{CV}>30)$. A low concentration of $\mathrm{Ca}+\mathrm{Mg}$ content was observed in both sampled areas, with averages of 2.7 and $1.7 \mathrm{cmol}_{\mathrm{c}} \mathrm{dm}^{-3}$ for areas A (Table 1) and B (Table 2), respectively.

This behavior is due to a greater use of these elements by soybean cultivation, especially during the grain-filling stage. Tables 1 and 2 also show the low $\mathrm{K}^{+}$contents, which is a reflection of intense leaching process due to a concentrated occurrence of precipitations during the period of soybean development (December to March). A low TOC content (Tables 1 and 2) is also an aggravating factor for this loss of $\mathrm{K}^{+}$since it decreases the number of charges that provide the essential $\mathrm{CEC}_{4.0}$ for $\mathrm{K}^{+}$adsorption (YARBOROUGH et al., 2017). Low TOC rates, even in areas under the no-tillage system, are also the result of the local climatic aggressiveness, mainly regarding high temperatures (annual average of $26.7{ }^{\circ} \mathrm{C}$ ). This temperature causes the microorganisms to quickly decompose the organic material on the soil, causing the organic carbon to quickly enter the oxidation stage and be lost to the atmosphere for being a sandy-loam soil. 
Table 1. Descriptive statistics of soil attributes for area A $(n=10)$.

\begin{tabular}{|c|c|c|c|c|c|c|c|c|}
\hline \multirow{2}{*}{ Soil attribute } & \multirow{2}{*}{ Mean } & \multirow{2}{*}{ Median } & \multicolumn{2}{|c|}{ Value } & \multirow{2}{*}{$\mathrm{SD}$} & \multicolumn{3}{|c|}{ Coefficient } \\
\hline & & & Min & $\operatorname{Max}$ & & Variation $(\%)$ & Asymmetry & Kurtosis \\
\hline $\mathrm{Ca}+\mathrm{Mg}\left(\mathrm{cmol}_{\mathrm{c}} \mathrm{dm}^{-3}\right)$ & 2.7 & 2.8 & 2 & 3.5 & 0.5 & 18 & -0.03 & -1.32 \\
\hline $\mathrm{K}^{+}\left(\mathrm{mg} \mathrm{dm}^{-3}\right)$ & 0.107 & 0.085 & 0.05 & 0.22 & 0.05 & 51 & 1.28 & 0.63 \\
\hline $\mathrm{P}\left(\mathrm{mg} \mathrm{dm}^{-3}\right)$ & 3.0 & 2.5 & 2 & 6.1 & 1.4 & 46 & 1.63 & 1.64 \\
\hline TOC $\left(\right.$ dag $\left.\mathrm{kg}^{-1}\right)$ & 3.9 & 3.6 & 2.9 & 5.9 & 1.0 & 26 & 1.24 & 0.39 \\
\hline $\mathrm{Al}^{3+}\left(\mathrm{cmol}_{\mathrm{c}} \mathrm{dm}^{-3}\right)$ & 0.21 & 0.19 & 0.10 & 0.48 & 0.13 & 62 & 1.13 & 0.36 \\
\hline $\mathrm{H}^{+}\left(\mathrm{cmol}_{\mathrm{c}} \mathrm{dm}^{-3}\right)$ & 5.8 & 5.8 & 4.6 & 7 & 0.7 & 12 & -0.08 & 0.54 \\
\hline $\mathrm{H}+\mathrm{Al}\left(\mathrm{cmol}_{\mathrm{c}} \mathrm{dm}^{-3}\right)$ & 6.0 & 6.0 & 4.8 & 7.2 & 0.7 & 12 & -0.01 & -0.47 \\
\hline $\mathrm{CEC}_{4.0}\left(\mathrm{cmol}_{\mathrm{c}} \mathrm{dm}^{-3}\right)$ & 3.1 & 3.1 & 2.2 & 3.9 & 0.5 & 17 & -0.11 & -0.72 \\
\hline $\mathrm{CEC}_{7.0}\left(\mathrm{cmol}_{\mathrm{c}} \mathrm{dm}^{-3}\right)$ & 8.9 & 9.0 & 7.6 & 10.1 & 0.8 & 9 & -0.34 & -1.08 \\
\hline V $(\%)$ & 32 & 32 & 25 & 39 & 5.1 & 16 & -0.12 & -1.71 \\
\hline $\mathrm{SB}\left(\mathrm{cmol}_{\mathrm{c}} \mathrm{dm}^{-3}\right)$ & 2.8 & 2.9 & 2.1 & 3.6 & 0.5 & 17 & 0 & -1.22 \\
\hline Sand $\left(\mathrm{g} \mathrm{kg}^{-1}\right)$ & 782 & 784 & 733 & 828 & 27 & 3 & -0.23 & 0.49 \\
\hline Silt $\left(\mathrm{g} \mathrm{kg}^{-1}\right)$ & 58 & 59 & 35 & 99 & 21 & 38 & 1.01 & 0.13 \\
\hline Clay $\left(\mathrm{g} \mathrm{kg}^{-1}\right)$ & 160 & 157 & 131 & 203 & 23 & 14 & 0.48 & -0.62 \\
\hline
\end{tabular}

Min=minimum; $M a x=$ maximum; $\mathrm{SD}=$ Standard deviation.

Table 2. Descriptive statistics of soil attributes for area B $(n=10)$.

\begin{tabular}{|c|c|c|c|c|c|c|c|c|}
\hline \multirow{2}{*}{ Soil attribute } & \multirow{2}{*}{ Mean } & \multirow{2}{*}{ Median } & \multicolumn{2}{|c|}{ Value } & \multirow{2}{*}{$\mathrm{SD}$} & \multicolumn{3}{|c|}{ Coefficient } \\
\hline & & & Min & Max & & Variation $(\%)$ & Asymmetry & Kurtosis \\
\hline $\mathrm{Ca}+\mathrm{Mg}\left(\mathrm{cmol}_{\mathrm{c}} \mathrm{dm}^{-3}\right)$ & 1.7 & 1.7 & 0.7 & 2.3 & 0.5 & 30 & -0.66 & -0.02 \\
\hline $\mathrm{K}^{+}\left(\mathrm{mg} \mathrm{dm}{ }^{-3}\right)$ & 0.09 & 0.08 & 0.03 & 0.19 & 0.05 & 56 & 1.08 & 1.01 \\
\hline $\mathrm{P}\left(\mathrm{mg} \mathrm{dm} \mathrm{dm}^{-3}\right)$ & 2.2 & 2.1 & 1.7 & 3.5 & 0.5 & 25 & 1.73 & 3.19 \\
\hline TOC (dag kg-1) & 2.4 & 2.2 & 0.5 & 5.0 & 1.3 & 52 & 0.62 & 0.53 \\
\hline $\mathrm{Al}^{3+}\left(\mathrm{cmol}_{\mathrm{c}} \mathrm{dm}^{-3}\right)$ & 0.25 & 0.24 & 0.10 & 0.48 & 0.15 & 59 & 0.22 & -1.79 \\
\hline $\mathrm{H}^{+}\left(\mathrm{cmol}_{\mathrm{c}} \mathrm{dm}^{-3}\right)$ & 5.2 & 5.1 & 4.3 & 6.7 & 0.8 & 15 & 0.73 & -0.01 \\
\hline $\mathrm{H}+\mathrm{Al}\left(\mathrm{cmol}_{\mathrm{c}} \mathrm{dm}^{-3}\right)$ & 5.4 & 5.3 & 4.4 & 6.8 & 0.8 & 15 & 0.52 & -0.75 \\
\hline $\mathrm{CEC}_{4.0}\left(\mathrm{cmol}_{\mathrm{c}} \mathrm{dm}^{-3}\right)$ & 2.0 & 2.1 & 1.4 & 2.5 & 0.4 & 19 & -0.30 & -1.39 \\
\hline $\mathrm{CEC}_{7.0}\left(\mathrm{cmol}_{\mathrm{c}} \mathrm{dm}^{-3}\right)$ & 7.2 & 7.3 & 5.9 & 8.9 & 0.9 & 13 & 0.27 & -0.08 \\
\hline V (\%) & 24 & 25 & 12 & 34 & 5.7 & 24 & -0.79 & 2.22 \\
\hline $\mathrm{SB}\left(\mathrm{cmol}_{\mathrm{c}} \mathrm{dm}^{-3}\right)$ & 1.8 & 1.8 & 0.9 & 2.4 & 0.5 & 27 & -0.47 & -0.63 \\
\hline Sand $\left(\mathrm{g} \mathrm{kg}^{-1}\right)$ & 865 & 867 & 841 & 884 & 17 & 2 & -0.39 & -1.45 \\
\hline Silt $\left(\mathrm{g} \mathrm{kg}^{-1}\right)$ & 50 & 46 & 36 & 65 & 10 & 21 & 0.15 & -1.42 \\
\hline Clay $\left(\mathrm{g} \mathrm{kg}^{-1}\right)$ & 85 & 87 & 65 & 104 & 13 & 15 & -0.24 & -1.08 \\
\hline
\end{tabular}

Min=minimum; Max=maximum; $\mathrm{SD}=$ Standard deviation. 
Organic material decomposition under the soil also presents an interference on $\mathrm{P}$ content (Tables 1 and 2), considering that the straw is an important P source. According to Zafar et al. (2017), the non-disturbance of soils in crops cultivated under no-tillage system avoids the exposure of new adsorption sites of the labile forms of $\mathrm{P}$, thus justifying the presence of higher $\mathrm{P}$ contents. In addition, considering that $\mathrm{P}$ is an immobile nutrient in soil and soil fertilization was carried out in the sowing groove, $\mathrm{P}$ tends to accumulate in the soil surface layer (DIEL et al., 2014). The maximum $P$ values were almost twice the minimum values for both datasets (Tables 1 and 2). This high amplitude in $\mathrm{P}$ contents reveals problems that can occur when the mean is used as the basis for decision making in the chemical management of agricultural areas, where at some sites the application dose will be low and in others, it will be above the required dose (DODERMANN; PING, 2004).

The content of $\mathrm{Al}^{3+}$ for both studied areas was considered low $\left(<0.50 \mathrm{cmol}_{\mathrm{c}} \mathrm{dm}^{-3}\right)$ (Tables 1 and 2 ). However, the coefficient of variation for this attribute was high in both areas (Tables 1 and 2). This value is due to a liming condition together with the no-tillage system, which cycles nutrients and reduces soil acidity. Zambrosi et al. (2007) found similar results. The areas presented low values of $\mathrm{CEC}_{4.0}$ and $\mathrm{CEC}_{7.0}$ (Tables 1 and 2). This feature is the result of the sum of some factors, such as a low TOC accumulation. In addition, the studied soil presents approximately 16 and $8 \%$ of clay for areas $\mathrm{A}$ and $\mathrm{B}$, respectively. This fraction is probably composed mostly of 1:1 silicate and oxidic clays, which exhibit less activity. The variable $\mathrm{V}$ presented an average of 32 for area A (Table 1) and 24 for area B. According to Campos et al. (2011), liming contributes to an increased $\mathrm{V}$ and a reduced aluminum saturation. However, this reduction in exchangeable $\mathrm{Al}^{3+}$ contents is not always related to base saturation due to liming, but to $\mathrm{Al}^{3+}$ complexation due to stable organic compounds.

\section{Pedotransfer functions}

Table 3 shows the pedotransfer functions calibrated with soil samples from area A in an attempt to estimate soil attributes via Munsell color parameters. Due to the low expression of contents of $\mathrm{Ca}+\mathrm{Mg}, \mathrm{K}^{+}, \mathrm{SB}$, and sand (Table 1), pedotransfer functions presented low $\mathrm{R}^{2}$ values $(<0.40)$ and high RMSE values $(>0.80)$, making it unfeasible to use these functions for estimating the attributes. In addition, these pedotransfer functions were significant (Table 3).

Among the functions calibrated for estimating $\mathrm{P}$, TOC, and V (Table 3), only those that used Hue as an indicator of soil attributes presented significance and acceptable values of precision $\left(\mathrm{R}^{2}=0.67\right.$ for $\mathrm{P}, \mathrm{R}^{2}=0.53$ for $\mathrm{TOC}$, and $\mathrm{R}^{2}=0.47$ for $\mathrm{V}$ ) and accuracy $(\mathrm{RMSE}=0.54$ for $\mathrm{P}, \mathrm{RMSE}=0.65$ for TOC, and RMSE $=0.69$ for V). However, in the validation procedure, no satisfactory results were found for TOC, considering that its $\mathrm{R}^{2}$ was very low $\left(\mathrm{R}^{2}=0.20\right)$. On the other hand, the estimation of $\mathrm{P}$ content using Hue as a predictor attribute is mainly associated with the goethite content of the studied soils since even with clay in low quantity, iron oxides (especially goethite) have a high power to fix P (DIEL et al. al., 2014). This feature leads the $P$ adsorbed on the surface of crystalline compounds to occur in relatively high amounts in most Brazilian soils, especially in places where climate promotes water stress (ROS et al., 2017). The infeasibility of building pedotransfer functions using the attributes Value and Chroma to estimate $\mathrm{P}$ is due to the low concentration of oxides in this soil. The infeasibility in estimating TOC by color is related to its low concentration at the study site. Even in the function with the use of Hue, the model does not present the maximum of its potential, which is also due to the low concentration of this attribute in the soil.

Demattê et al. (2011) found that Value and Chroma are not effective in predicting TOC. This can be easily seen in the Munsell color 
chart, where the highest values of Chroma and Value are observed for soils with lighter colors, generally indicating low TOC contents (DANTAS et al., 2014). All models calibrated to estimate $\mathrm{Al}^{3+}$ presented significance (Table 3 ), with an $\mathrm{R}^{2}$ value above $50 \%$. With validation, the function that best fit for the estimation was the one that uses Hue as a predictor. However, all three functions presented low precision values. The model generated for estimating the attribute $\mathrm{H}^{+}$(Table 3) presented significance for the parameters Hue $\left(\mathrm{R}^{2}=0.84\right.$ and $\mathrm{RMSE}=0.38)$ and Chroma $\left(\mathrm{R}^{2}=0.60\right.$ and RMSE $=0.59$ ), thus indicating a strong linear relationship between these variables. This fact can be proven by observing the validation results, especially for the function where Chroma is used as a predictor of $\mathrm{H}^{+}$. Likewise, only the models that used Hue $\left(\mathrm{R}^{2}=\right.$ 0.90 and $\mathrm{RMSE}=0.29)$ and Chroma $\left(\mathrm{R}^{2}=0.54\right.$ and RMSE $=0.64)$ presented significance $(p<0.05)$ for estimating $\mathrm{H}+\mathrm{Al}$ (Table 3 ).

Table 3. Calibration $(n=10)$ and validation $(n=10)$ of the pedotransfer functions of the Munsell parameters.

\begin{tabular}{|c|c|c|c|c|c|}
\hline \multirow{2}{*}{ Soil attribute } & \multirow{2}{*}{ Pedotransfer function } & \multicolumn{2}{|c|}{ Calibration } & \multicolumn{2}{|c|}{ Validation } \\
\hline & & $\mathrm{R}^{2}$ & RMSE & $\mathrm{R}^{2}$ & RMSE \\
\hline \multirow{3}{*}{$\begin{array}{c}\mathrm{Ca}+\mathrm{Mg} \\
\left(\mathrm{cmol}_{\mathrm{c}} \mathrm{dm}^{-3}\right)\end{array}$} & $4.2452-0.1666 *$ Hue & 0.07 & 0.91 & - & - \\
\hline & $15.273-3.1672 *$ Value & 0.37 & 0.75 & - & - \\
\hline & $8.5285-2.0485 *$ Chroma & 0.36 & 0.75 & - & - \\
\hline \multirow{3}{*}{$\begin{array}{c}\mathrm{K}^{+} \\
\left(\mathrm{mg} \mathrm{dm}^{-3}\right)\end{array}$} & $-0.112+0.0247 *$ Hue & 0.19 & 0.85 & - & - \\
\hline & $-0.6347+0.1858 *$ Value & 0.22 & 0.83 & - & - \\
\hline & $-0.2867+0.1451 *$ Chroma & 0.16 & 0.86 & - & - \\
\hline \multirow{3}{*}{$\begin{array}{c}\mathrm{P} \\
\left(\mathrm{mg} \mathrm{dm}^{-3}\right)\end{array}$} & $12.051-1.1175 *$ Hue & 0.67 & $0.54 *$ & 0.40 & 3.75 \\
\hline & $20.34-4.371 *$ Value & 0.08 & 0.90 & - & - \\
\hline & $5.8488-1.1312 *$ Chroma & 0.04 & 0.92 & - & - \\
\hline \multirow{3}{*}{$\begin{array}{c}\text { TOC } \\
\left.\left(\text { dag }^{-1}\right)^{-1}\right)\end{array}$} & $10.667-0.8398 *$ Hue & 0.53 & $0.65 *$ & 0.20 & 1.97 \\
\hline & $-1.8891+1.4259 *$ Value & 0.02 & 0.93 & - & - \\
\hline & $-0.8933+1.6604 *$ Chroma & 0.08 & 0.90 & - & - \\
\hline \multirow{3}{*}{$\begin{array}{c}\mathrm{Al}^{3+} \\
\left(\mathrm{cmol}_{\mathrm{c}} \mathrm{dm}^{-3}\right)\end{array}$} & $-2.4954+0.3181 *$ Hue & 0.54 & $0.64 *$ & 0.35 & 3.10 \\
\hline & $4.8353-1.1937 *$ Value & 0.65 & $0.55^{*}$ & 0.03 & 1.39 \\
\hline & $1.4029-0.4455^{*}$ Chroma & 0.50 & $0.66 *$ & 0.01 & 1.17 \\
\hline \multirow{3}{*}{$\begin{array}{c}\mathrm{H}^{+} \\
\left(\mathrm{cmol}_{\mathrm{c}} \mathrm{dm}^{-3}\right)\end{array}$} & $-1.4785+0.8838 *$ Hue & 0.84 & $0.38 *$ & 0.40 & 0.79 \\
\hline & $19.174-3.4368 *$ Value & 0.12 & 0.89 & - & - \\
\hline & $13.159-2.5941 *$ Chroma & 0.60 & $0.59 *$ & 0.49 & 1.67 \\
\hline \multirow{3}{*}{$\begin{array}{c}\mathrm{H}+\mathrm{Al} \\
\left(\mathrm{cmol}_{\mathrm{c}} \mathrm{dm}^{-3}\right)\end{array}$} & $-9.29+1.8167 *$ Hue & 0.90 & $0.29 *$ & 0.40 & 2.46 \\
\hline & $24.009-4.6305 *$ Value & 0.19 & 0.85 & - & - \\
\hline & $14.023-2.8288 *$ Chroma & 0.54 & $0.64 *$ & 0.42 & 1.45 \\
\hline \multirow{3}{*}{$\begin{array}{c}\mathrm{CEC}_{4.0} \\
\left(\mathrm{cmol}_{\mathrm{c}} \mathrm{dm}^{-3}\right)\end{array}$} & $4.0884-0.1286 *$ Hue & 0.02 & 0.93 & - & - \\
\hline & $14.45-2.8754 *$ Value & 0.26 & 0.81 & - & - \\
\hline & $9.5189-2.2878 *$ Chroma & 0.39 & 0.74 & - & - \\
\hline \multirow{3}{*}{$\begin{array}{c}\mathrm{CEC}_{7.0} \\
\left(\mathrm{cmol}_{\mathrm{c}} \mathrm{dm}^{-3}\right)\end{array}$} & $2.1793+0.8256 *$ Hue & 0.65 & $0.56^{*}$ & 0.68 & 1.59 \\
\hline & $36.742-7.1488 *$ Value & 0.32 & 0.77 & - & - \\
\hline & $19.181-3.658 *$ Chroma & 0.59 & $0.60 *$ & 0.57 & 2.71 \\
\hline
\end{tabular}


continuation

$\begin{array}{cccccc} & 73.309-4.8484 * \text { Hue } & 0.47 & 0.69 * & 0.42 & 2.46 \\ \mathrm{~V} & 143.78-28.143 * \text { Value } & 0.36 & 0.76 & - & - \\ (\%) & 69.653-13.104 * \text { Chroma } & 0.18 & 0.85 & - & - \\ & 4.3958-0.1888^{*} \text { Hue } & 0.06 & 0.91 & - & - \\ \mathrm{SB} & 14.933-3.0521 * \text { Value } & 0.34 & 0.77 & - & - \\ \left(\mathrm{cmol}_{\mathrm{c}} \mathrm{dm}^{-3}\right) & 8.4633-1.9846 * \text { Chroma } & 0.34 & 0.77 & - & - \\ & 1145.6-42.329 * \text { Hue } & 0.26 & 0.81 & - & - \\ \text { Sand } & 1250.6-120.84 * \text { Value } & 0.26 & 0.81 & - & - \\ \left(\mathrm{g} \mathrm{kg}^{-1}\right) & 668.65+43.687 * \text { Chroma } & 0.11 & 0.89 & - & - \\ & 205.62-18.178 * \text { Hue } & 0.28 & 0.80 & - & - \\ \text { Silt } & 948.7-229.08 * \text { Value } & 0.50 & 0.67 & - & - \\ \left(\mathrm{g} \mathrm{kg}^{-1}\right) & 339.79-101.5 * \text { Chroma } & 0.43 & 0.71 * & 0.11 & 3.14 \\ & 10.262+18.371 * \text { Hue } & 0.24 & 0.82 & - & - \\ \mathrm{Clay}^{\left.-\mathrm{g} \mathrm{kg}^{-1}\right)} & -578.92+189.74 * \text { Value } & 0.64 & 0.57 * & 0.46 & 7.27 \\ \end{array}$

*Significant at 5\% probability level.

Validation procedure indicated that Chroma is also more efficient in estimating $\mathrm{H}+\mathrm{Al}$ when compared to Hue. The behavior found for the calibration functions of $\mathrm{CEC}_{7.0}$ (Table 3) were also similar, presenting $\mathrm{R}^{2}$ values of 0.65 and 0.59 and RMSE values of 0.56 and 0.60 for Hue and Chroma, respectively. However, in the validation, the behavior was the opposite, with Hue being more efficient in estimating $\mathrm{CEC}_{7.0}$ when compared to Chroma, with $\mathrm{R}^{2}$ values of 0.68 and 0.57 and RMSE values of 1.59 and 2.71 for both, respectively. This result is related to the presence of kaolinite and iron and aluminum oxides that dominate the clay fraction (SANTOS et al., 2009).

For particle size attributes, only the functions for estimating silt using Chroma $\left(\mathrm{R}^{2}=0.43\right.$ and $\mathrm{RMSE}$ $=0.71)$ and clay using Value $\left(\mathrm{R}^{2}=0.64\right.$ and $\mathrm{RMSE}$ $=0.57)$ presented significance $(\mathrm{p}<0.05)$ (Table 3$)$. This behavior is associated with the crystalline reflection of silt and expression of oxides. However, the indices of precision and accuracy of validation showed that only clay could be estimated by Value.

\section{Conclusions}

This study shows the potential of using the three parameters of the Munsell color system (Hue, Value, and Chroma) in estimating different chemical and particle size attributes by pedotransfer functions in a Typic Hapludox in the Cerrado of Piauí State, Brazil. Hue can be used to estimate $\mathrm{P}, \mathrm{Al}, \mathrm{H}^{+}, \mathrm{H}+\mathrm{Al}$, $\mathrm{CEC}_{70}$, and $\mathrm{V}$, Value for clay, and Chroma for $\mathrm{H}^{+}$, $\mathrm{H}+\mathrm{Al}$, and $\mathrm{CEC}_{7.0}$. However, future studies are still necessary for the improvement of this technique, as well as its evaluation in different types of soil, geology, and cultivation systems, enabling more and more the use of color in estimating soil attributes.

\section{Acknowledgments}

The authors are grateful to the Graduate Program in Agronomy - Soils and Plant Nutrition of the Federal University of Piauí/Campus Professor Cinobelina Elvas and the São Paulo State University "Júlio de Mesquita Filho"/Campus of Jaboticabal for the facilities that provided the conditions for 
this research. To Mr. Ronaldo Marafon for the experimental areas. To all undergraduate and graduate students from the Federal University of Piauí/Campus Professor Cinobelina Elvas and São Paulo State University "Júlio de Mesquita Filho"/ Campus of Jaboticabal for assisting the field work and performing the analyses. To CAPES for the master's degree scholarship (social demand) of the first author.

\section{References}

ASCHERI, D. P. R.; MORAIS, C. C.; ASQUIERI, E. R.; CARVAlHO, C. W. P.; ASCHERI, J. L. R. Characterization of starch extracted from the roots of Cissussimsiana Roem. \& Schult. Semina: Ciências Agrárias, Londrina, v. 35, n. 2, p. 787-800, 2014.

BAUMANN, K.; SCHÖNING, I.; SCHRUMPF, M.; ELLERBROCK, R. H.; LEINWEBER, P. Rapid assessment of soil organic matter: Soil color analysis and Fourier transform infrared spectroscopy. Geoderma, Amsterdam, v. 278, p. 49-57, 2016.

CAMPOS, L. P.; LEITE, L. F. C.; MACIEL, G. A.; IWATA, B. F.; NÓBREGA, J. C. A. Atributos químicos de um latossolo amarelo sob diferentes sistemas de manejo. Pesquisa Agropecuária Brasileira, Brasília, v. 46, n. 12, p. 1681-1689, 2011.

CARMO, D. A. B. do; MARQUES JÚNIOR, J.; SIQUEIRA, D. S.; BAHIA, A. S. R. S.; SANTOS, H. M.; POLLO, G. Z. Cor do solo na identificação de áreas com diferentes potenciais produtivos e qualidade de café. Pesquisa Agropecuária Brasileira, Brasília, v. 51, n. 9, p. 1261-1271, 2016.

DANTAS, J. S.; MARTINS FILHO, M. V.; MARQUES JÚNIOR, J.; RESENDE, J. M. A. R.; TEIXEIRA, D. B.; BARBOSA R. S.; SIQUEIRA, D. S. Coeficiente de erodibilidade em sulcos e entressulcos de Argissolos coesos estimado pela cor do solo. Pesquisa Agropecuária Brasileira, Brasília, v. 48, n. 9, p. 700-707, 2014.

DEMATTÊ, J. A. M.; BORTOletTO, M. A. M.; VASQUES, G. M.; RIZZO, R. Quantificação de matéria orgânica do solo através de modelos matemáticos utilizando colorimetria no sistema Munsell de cores. Bragantia, Campinas, v. 70, n. 3, p. 590-597, 2011.

DEMATTÊ, J. A. M.; TERRA, F. S. Spectral pedology: a new perspective on evaluation of soils along pedogenetic alterations. Geoderma, Amsterdam, v. 217-218, p. 190$200,2014$.
DIEL, D.; BEHLING, M.; FARIAS NETO, A. L.; ISERNHAGEN, E. C. C. Distribuição horizontal e vertical de fósforo em sistemas de cultivos exclusivos de soja e de integração lavoura-pecuária-floresta. Pesquisa Agropecuária Brasileira, Brasília, v. 49, n. 8, p. 639-647, 2014.

DODERMANN, A.; PING, J. L. Geostatistical integration of yield monitor data and remote sensing improves yield maps. Agronomy Journal, Madison, v. 96, n. 1, p. 285297, 2004.

DONAGEMA, G. K.; CAMPOS, D. V. B.; CALDERANO, S. B. de; TEIXEIRA, W. G.; VIANA, J. H. M. (Ed.). Manual de métodos de análise de solos. 2. ed. rev. Rio de Janeiro: EMBRAPA Solos, 2011. 230 p. (EMBRAPA Solos. Documentos, 132).

DRANSKI, J. A. L.; MALAVASI, U. C.; MALAVASI, M. M. Estimating chlorophyll content from Eucalyptus dunnii leaves by reflectance values. Semina: Ciências Agrárias, Londrina, v. 37, n. 3, p. 1277-1284, 2016.

FERNANDES, K. L.; RIBON, A. A.; MARQUES JÚNIOR, J.; BAHIA, A. S. R. S.; TAVARES FILHO, J. Characterization, classification and analysis of the main properties of the Southwestern Goias soil. Semina: Ciências Agrárias, Londrina, v. 37, n. 3, p. 1135-1154, 2016.

GÓMEZ, C.; LE BISSONNAIS, Y.; ANNABI, M.; BAHRI, H.; RACLOT, D. Laboratory Vis-NIR spectroscopy as an alternative method for estimating the soil aggregate stability indexes of Mediterranean soils. Geoderma, Amsterdam, v. 209, p. 86-97, 2013.

HOLMES, K. W.; CHADWICK, O. A.; KYRIAKIDIS, P. C. Error in a USGS 30-meter digital elevation model and its impact on terrain modeling. Journal of Hydrology, v. 233, n. 1-4, p. 154-173, 2000.

KIRILLOVA, N. P.; VODYANITSKII, Y. N.; SILEVA, T. M. Conversion of soil color parameters from the Munsell system to the CIE-L*a*b* system. Eurasian Soil Science, Moscow, v. 48, n. 5, p. 468-475, 2015.

NONAKA, A. G.; BATISTA, M. A.; INOUE, T. T.; COSTA, A. C. S. da. Thermal transformation and characterization of synthetic al-Substituted maghemites $\left(\gamma-\mathrm{Fe}_{2-\mathrm{x}} \mathrm{Al}_{\mathrm{x}} \mathrm{O}_{3}\right)$. Revista Brasileira de Ciência do Solo, Viçosa, MG, v. 40, p. 1-13, 2016.

PELUCO, R. G.; MARQUES JÚNIOR, J.; SIQUEIRA, D. S.; PEREIRA, G. T.; BARBOSA, R. S.; TEIXEIRA, D. B. Mapeamento do fósforo adsorvido por meio da cor e da suscetibilidade magnética do solo. Pesquisa Agropecuária Brasileira, Brasília, v. 50, n. 3, p. 259-266, 2015. 
RABENHORST, M. C.; MATOVICH, M. M.; ROSSI, A. M.; FENSTERMACHER, D. E. Visual assessment and interpolation of low chroma soil colors. Soil Science Society of America Journal, Madison, v. 78, n. 2, p. 567570, 2014.

ROS, C. O. da; MATSUOKA, M.; SILVA, R. F.; SILVA, $\mathrm{V}$. R. Interference from the vertical variation of soil phosphorus and from water stress on growth in maize, the soybean and sunflower. Revista Ciência Agronômica, Fortaleza, v. 48, n. 3, p. 419-427, 2017.

RUBIO, F.; MENEGHEL, A. P.; GOMES, L. F. S.; MALAVASI, M. M. Estádios de maturação do fruto no desempenho germinativo e teor de óleo de sementes de Jatrophacurcas Linn. Semina: Ciências Agrárias, Londrina, v. 34, n. 2, p. 663-668, 2013.

SANTOS, H. G.; JACOMINE, P. K. T.; ANJOS, L. H. C.; OLIVEIRA, V. A.; LUMBRERAS, J. F.; COELHO, M. R.; ALMEIDA, J. A.; CUNHA, T. J. F.; OLIVEIRA, J. B. (Ed.). Sistema brasileiro de classificação de solos. 3. ed. rev. e ampl. Rio de Janeiro: EMBRAPA Solos, 2013. $353 \mathrm{p}$.

SANTOS, V. R.; MOURA FILHO, G.; SANTOS, C. G.; SANTOS, M. A. L.; CUNHA, J. L. X. L.; Contribuição de argilominerais e da matéria orgânica na CTC dos solos do estado de alagoas. Caatinga, Mossoró, v. 22, n. 1, p. 27-36, 2009.

SILVA, R. F.; SANTOS, G. G.; NÓBREGA, J. C. A.; OLIVEIRA, G. C.; DIAS, B. O.; SANTOS, D. P.; SILVA JÚNIOR, J. P. Impacts of land-use and management systems on organic carbon and water-physical properties of a LatossoloAmarelo (Oxisol). Semina: CiênciasAgrárias, Londrina, v. 38, n. 1, p. 109-124, 2017.
SORIANO-DISLA, J. M.; JANIK, L. J.; VISCARRA ROSSEL, R.A.; MACDONALD,L.M.; MCLAUGHLIN, M. J. The performance of visible, near-, and midinfrared reflectance spectroscopy for prediction of soil physical, chemical, and biological properties. Applied Spectroscopy Reviews, Los Angeles, v. 49, n. 2, p. 139186, 2014.

STIGLITZ, R.; MIKHAILOVA, E.; POST, C.; SCHLAUTMAN, M.; SHARP, J.; PARGAS, R.; GLOVER, B.; MOONEY, J. Soil color sensor data collection using a GPS-enabled smartphone application. Geoderma, Amsterdam, v. 296, p. 108-114, 2017.

VODYANITSKII, Y. N.; KIRILLOVA, N. P. Application of the CIE-L*a*b* system to characterize soil color. Eurasian Soil Science, Moscow, v. 49, n. 11, p. 12591268, 2016.

YARBOROUGH, J. K.; VENDRAMINI, J. M. B.; SILVEIRA, M. L.; SOLLENBERGER, L. E.; LEON, R. G.; SANCHEZ, J. M. D.; OLIVEIRA, F. C. L. de; KUHAWARA, F. A.; GOMES, V.; CECATO, U.; SOARES, C. V. Impact of potassium and nitrogen fertilization on bahiagrass herbage accumulation and nutrient concentration. Agronomy Journal, Madison, v. 109, n. 3, p. $1099-1105,2017$.

ZAFAR, M.; TIECHER, T.; CAPOANE, V.; TROIAN, A.; SANTOS, D. R. dos. Characteristics, lability and distribution of phosphorus in suspended sediment from a subtropical catchment under diverse anthropic pressure in Southern Brazil. Ecological Engineering, Índia, v. 100, p. 28-45, 2017.

ZAMBROSI, F. C. B.; ALLEONI, L. R. F.; CAIRES, E. F. Aplicação de gesso agrícola e especiação iônica da solução de um Latossolo sob sistema plantio direto. Ciência Rural, Santa Maria, v. 37, n. 1, p. 110-117, 2007. 